\title{
Raně středověké říční koryto v blízkosti fortifikačního systému velkomoravského hradiska Pohansko u Břeclavi
}

\author{
The Early Medieval fluvial channel within the defence system of the Great Moravia \\ Empire agglomeration Pohansko near Břeclav
}

\author{
Slavomír Nehyba' $\square$, Petr Dresler², Nela Doláková', František Kuda ${ }^{3}$, \\ Michaela Prištáková2 , Jakub Šimík ${ }^{2}$, Jaroslav Škojec ${ }^{4}$, Karel Kirchner ${ }^{3}$ \\ ' Ústav geologických věd, Přírodovědecká fakulta, Masarykova univerzita, Kotlářská 2, 61137 Brno, Česká republika \\ 2 Ústav archeologie a muzeologie, Filosofická fakulta, Masarykova univerzita, Arna Nováka 1, 60200 Brno, Česká republika \\ ${ }^{3}$ Oddělení environmentální geografie Ústav geoniky AV ČR, v. v. i., Drobného 28, 60200 Brno, Česká republika \\ ${ }^{4}$ Mikulčice - výzkumná základna, Archeologický ústav AV ČR, Brno, v. v. i., Čechyňská 363/19, 60200 Brno, Česká republika
}

\section{Key words:}

fluvial channel, absolute-age dating techniques, medieval fortification, paleogeographic reconstruction

\section{$\triangle$ slavek@sci.muni.cz}

Editor:

Martin Ivanov

\author{
Doporučená citace článku: \\ Nehyba, S., Dresler, P., Doláková, \\ N., Kuda, F., Prištáková, M., Šimík, \\ J.,Škojec, J., Kirchner, K. (2020). \\ Raně středověké ríční koryto \\ $v$ blizkosti fortifikačního systému \\ velkomoravského hradiska Pohansko \\ u Břeclavi. - Geologické výzkumy \\ na Moravě a ve Slezsku, 27, 1-2, \\ $54-62$.
}

DOI: https://doi.org/10.5817/ GVMS2020-13285

\begin{abstract}
Geophysical, sedimentological, palynological, absolute-age dating and archeological techniques were used to study the deposits of the Early Medieval fluvial channel in the area of the Great Moravia Empire agglomeration Pohansko near Břeclav. Artificial profile situated on the base of ERT profiles and the archeological results led to opening of the fluvial channel. Newly documented fluvial channel erosively cut the complex of flood loams. Gravel lag covers the bottom of the channel and grade upwards into sandy channel infill with fining upward trend. Fluvial sandy dunes forming the most characteristic architectural element of the infill are represented mostly by trough cross-stratified medium-grained sands. These sands were penetrated by the piece of oak wood. Both the OSL dating of the sandy deposits and the dating of the oak wood $\left({ }^{14} \mathrm{C}\right.$ and dendrochronology) point to the 9 th century $A D$ when the Great Moravia Empire was on its peak expansion. Active fluvial channel was probably used as a part of the fortification system and a possible wood bridge existed here in the front of the proposed Western Gate of the Pohansko agglomeration. Palynological studies reveal some fragmentation of the landscape and agricultural activities in the close surroundings. Deposits of the studied fluvial channel were covered by the beds of the younger flood loams.
\end{abstract}

\section{Úvod}

Výzkum zaniklých koryt v blízkosti velkomoravského hradiska na Pohansku u Břeclavi se ve srovnání s předcházejícími padesáti lety výrazně rozvinul. Nejnovější pozornost však byla věnována jen prostoru Severovýchodního předhradí v souvislosti s realizovaným archeologickým výzkumem (Dresler et al. 2014; Petr et al. 2015; Petřík et al. 2018). Výzkum říčního koryta v př́mém vztahu s opevněním centrálního areálu Pohanska byl naposledy řešen jen při výzkumu Východní brány, kde bylo koryto zachyceno okrajově (Dostál, Štelcl 1985). Navazující geofyzikální výzkum doplněný vrty existenci koryta v těsné blízkosti brány potvrdil (Voňka 1985). Proto jsme se rozhodli provést předběžný průzkum v návaznosti na prostor předpokládané západní brány, kde studiem geomorfologie byla již dříve zjištěna výrazná modelace průběhu pohanského písčitého hrúdu v přímé návaznosti na linii destrukce opevnění a kde je předpokládán i hlavní tok Dyje (Dresler 2011). Zájmové území je znázorněno na obrázku 1.

\section{Geologické poměry}

Zájmová oblast je dnes situována v zalesněných mokřadech v ploché údolní nivě dolního toku řeky Dyje poblíž jejího soutoku s řekou Moravou (nadmořské výšky se zde pohybují přibližně kolem 155 až 157 m nad mořem). Rozsáhlá údolní 


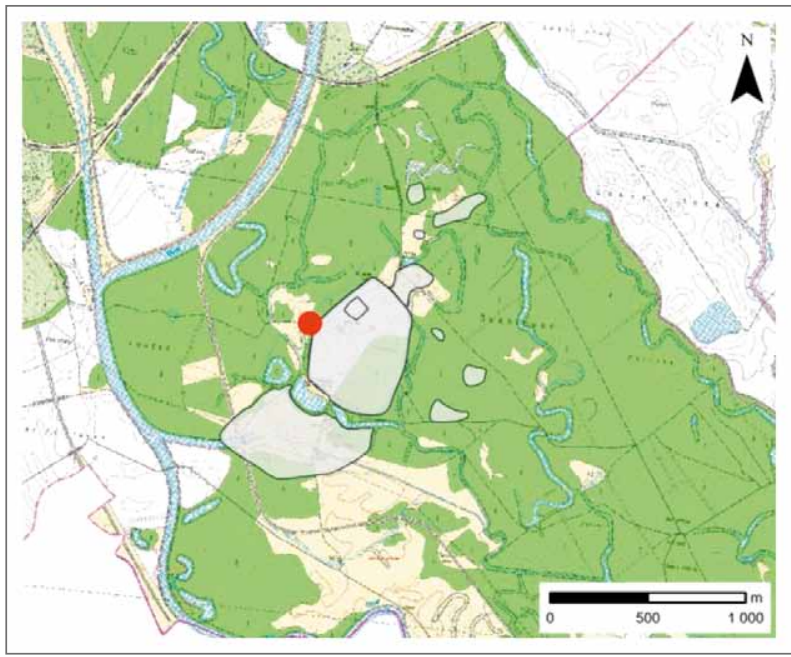

Obr. 1: Lokalizace zájmového území.

Fig. 1: Location of the area of interest.

niva Dyje, která je zde až 8 km široká, je protkána řadou říčních koryt a opuštěných říčních ramen. Moderní vlivy člověka (sídelní struktury, odlesnění a úpravy terénu) jsou zde v krajině relativně malé, což je způsobeno jak historicky, tak př́hraniční lokací podél státní hranice s Rakouskem. Jeden z vrcholů osídlení a lidského vlivu na krajinu studované oblasti je tak spojován s existencí státního útvaru Velké Moravy, kdy byly sídelní aglomerace umístěny přímo $\mathrm{v}$ říční nivě.

Mělké vrty v oblasti hradiště Pohansko zastihly v podloží kvartérních sedimentů neogenní panonské jíly vídeňské pánve ( $\mathrm{v}$ hloubkách kolem $8 \mathrm{~m}$ ). Jsou pokryty svrchnopleistocenními až spodnoholocenními říčními písky a písčitými štěrky (Macháček et al. 2007). Jejich stáří je relativně proměnlivé (22 $400 \mathrm{BP}$ - podle Havlíček 2004: 13500 a 11 800; 10300 BP podle Nehyba et al. 2018). Tyto písčité fluviální sedimenty jsou překryty komplexem písčitých a jílovitých povodňových hlín, prrípadně jílovitými písky až písčitými jíly (Havlíček 2004; Doláková et al. 2010). Tyto sedimenty byly interpretovány jako sedimenty říčních koryt a přelivové sedimenty, dále jako eolické písky a subfosilní půdy (holocenního stárí), které odrážejí komplikovanou historii vyplňování říční nivy. Dosažitelné výsledky datování metodou ${ }^{14} \mathrm{C}$ data (Havlí-

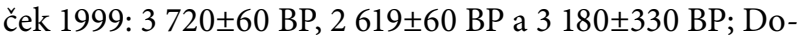

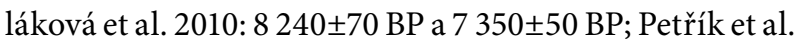

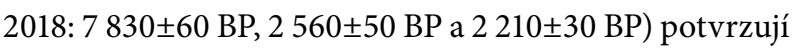
stáří stř̌edního až svrchního holocénu a komplikovanou historii agradace. Další etapa rozsáhlé sedimentace povodňových hlín je spojena s koncem středověku a časným novověkem (Dresler 2016). Mocnost těchto hlín může dosáhnout až několik m (Havlíček 2001).

Nepravidelné písčité elevace („hrúdy“) známé z údolní nivy zájmové oblasti byly mimořádně vhodné pro raně středověké osídlení. Komplikovaná geneze těchto elevací ukazuje ve světle současného stavu poznání především na fluviální procesy (fluviální tělesa jako vnitrokorytové nebo jesepní valy) s určitou rolí redepozice vlivem činnosti eolické a s vlivem pedogeneze (Havlíček, Smolíková 2002; Havlíček et al. 2016; Nehyba et al. 2018;
Petřík et al. 2018). Výhradně eolický původ těchto elevací je těmito pracemi do jisté míry zpochybněn.

\section{Metodika práce}

V prostoru předpokládané západní brány hradiště byly nejprve vytyčeny a následně změřeny dva geoelektrické profily metodou elektrické odporové tomografie (ERT). Pro měření byla využita aparatura ARES (výrobce GF Instruments, s.r.o., Česká republika) a 9 sekcí aktivních multielektrodových kabelů. Průzkum byl realizován na profilech s délkou $71 \mathrm{~m}$ při rozestupu elektrod $1 \mathrm{~m}$ a typu uspořádání Wenner-Schlumberger. Počátek profilů (M1 a M2) byl položen na okraj asfaltové komunikace, která vede po akumulaci destruovaného opevnění hradiska (Dresler 2011 používá pro tento tvar termín destrukce opevnění). Z příkrého svahu destrukce opevnění jsou profily vedeny přes výraznou terénní vlnu (snad snížená část duny - viz též Dresler 2011, s. 36) a zahloubenou vodoteč na plochý akumulační povrch údolní nivy směrem k SZ. Naměřené ERT profily (pozice znázorněna na obrázku 2) byly standardně zpracovány programem Res2DInv a graficky vizualizovány v programu Surfer do jednotné barevné stupnice. Výběr výsledné varianty modelu (iterace) byl proveden na základě statistické a vizuální shody naměřených hodnot zdánlivého měrného odporu (Rz) a vypočítaných modelových odporů (Rm).

$\mathrm{Na}$ základě těchto výsledků byla následně poblíž části profilu M1 provedena průzkumná rýha v délce asi $26 \mathrm{~m}$ a hloubce kolem $2 \mathrm{~m}$ (viz obr. 2). Stěny rýhy byly geodeticky zaměřeny, kresebně dokumentovány, litologicky popsány, provedena faciální analýza dle Tucker (1988), Walker, James (1992) a Nemec (2005) a dále byla hodnocena architektura sedimentárních těles. Odebrané vzorky jednotlivých sedimentu litofacií byly vyhodnoceny metodami granulometrické analýzy (kombinace metody

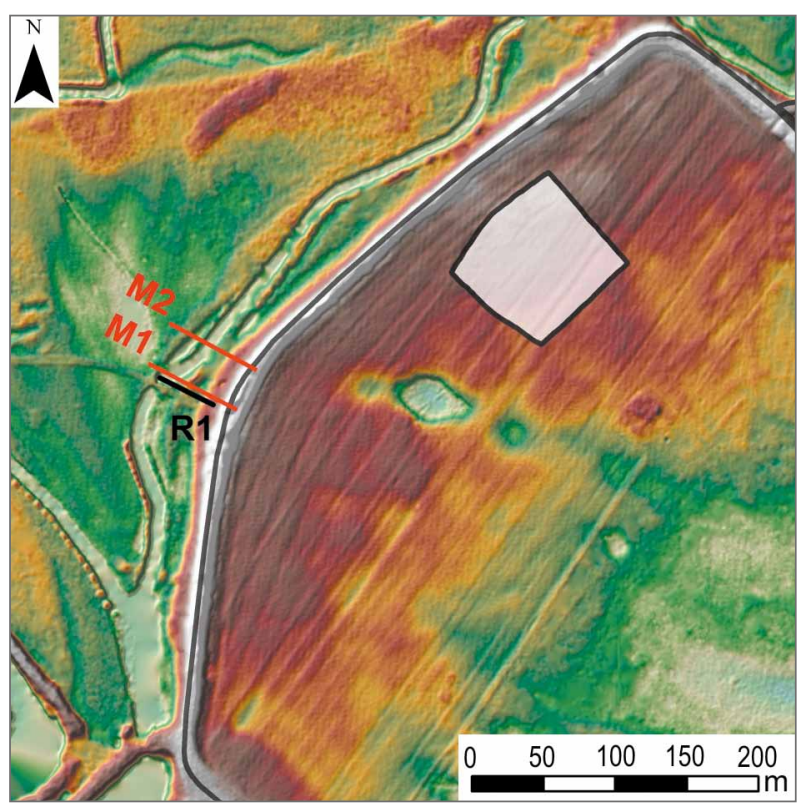

Obr. 2: Lokalizace měřených ERT profilů (M1 a M2) v digitální mapě reliéfu s vyznačením umělé rýhy $(\mathrm{R} 1)$.

Fig. 2: Location of the measured ERT profiles (M1 and M2) in digital elevation model with position of artificial profile (R1). 
sítování za mokra na normovaných sítech a sítovacím přístroji Retsch AS - 200 a laserové difrakce s použitím granulometru CILAS 1064. K určení zrnitostních charakteristik (Mz, $\sigma \mathrm{I})$ byly využity vzorce dle Folk, Ward (1957).

Odebraný vzorek písku z rríčního koryta byl datován metodou opticky stimulované luminiscence (OSL). Datování bylo provedeno formou zakázky v OSL centru GADAM Gliwice (Polsko).

Ve dně koryta byl identifikován zaražený zašpičatělý dřevěný kůl, který byl po vyzvednutí a dokumentaci podroben dendrochronologické analýze na pracovišti Archeologického ústavu AV ČR v Mikulčicích Jaroslavem Škojcem. Pro kontrolu vzorek opět analyzoval Tomáš Kyncl, který doporučil kontrolní datování pomoci C14 analýzy. Radiokarbonové datování vybraných letokruhů bylo provedeno $\mathrm{v}$ radiokarbonové laboratoři v Poznani (Polsko). Radiokarbonová data byla kalibrována metodou Wiggle-match v programu OxCal - v 4.3 Web interface build number: 120 (Bronk Ramsey, Lee 2013), při použití kalibrační křivky InCal13 (Reimer et al. 2013).

Z průzkumné rýhy bylo odebráno 8 vzorků na palynologická studia. Vzorky byly laboratorně zpracovány metodou macerace $(\mathrm{HCl}, \mathrm{HF}, \mathrm{KOH})$ a acetolýzy $\left(\mathrm{H}_{2} \mathrm{SO}_{4}\right.$ $\left.+\left(\mathrm{CH}_{3} \mathrm{CO}\right)_{2} \mathrm{O}\right)$. $\mathrm{Z}$ důvodi̊ zkoncentrování obsahu palynomorf bylo využito těžké kapaliny $\mathrm{ZnCl}_{2}$. Determinace palynomorf byla prováděna optickým mikroskopem Nikon Alphaphot 2, zejména podle prací Beug (2004) a Reille (1999). Pylový diagram byl zpracován programem POLPAL (Walanus, Nalepka 1999).

\section{Výsledky}

Výsledky geolelektrického profilování jsou prezentovány na obrázku 3A a B. Pouhé vizuální srovnání profilů ukazuje na jejich podobnost v rozložení polí rezistivit i nehomogenit. Podobné je i naměřené široké pole hodnot rezistivity. Generelně vyšší hodnoty lze pozorovat ve svrchních $8-10 \mathrm{~m}$ profilů a také v počátečních metrech měřených tras. Interpretace výsledků ERT vychází z předpokladu, že měrný odpor je v přímém vztahu s parametry, jako jsou typ horniny, pórovitost, stupeň nasycení vodou (Císlerová et al. 2006). Na tomto základě a vzhledem $\mathrm{k}$ dosavadním znalostem geologické stavby zájmové oblasti bylo usuzováno na stavbu zájmových profilů. Drobné odchylky zvýšené či snížené rezistivity jsou způsobeny citlivostí metody na umístění jednotlivých elektrod a na kontakt elektrod s půdou (Zumr et al. 2009). Nepříznivé klimatické podmínky spojené se značným suchem zkomplikovaly výsledky měření.

Konvexní průběh vybraných geoelektrických polí s centrálními partiemi s vyššími odpory vůči jejich periferiím byly dobrým předpokladem existence fluviálních koryt (vzhledem k dosavadním poznatkům o geologické stavbě zájmového území). S ohledem na hloubkovou a prostorovou pozici těchto polí byl následně strojově proveden liniový výkop. Faciální analýza takto odkrytého více než $26 \mathrm{~m}$ dlouhého a místy přes $2 \mathrm{~m}$ vysokého profilu odkrytého výkopem vedla k vyčlenění 8 litofacií. Základní litologické charakteristiky vyčleněných litofacií jsou uvedeny v tabulce 1 a vybraný litologický profil
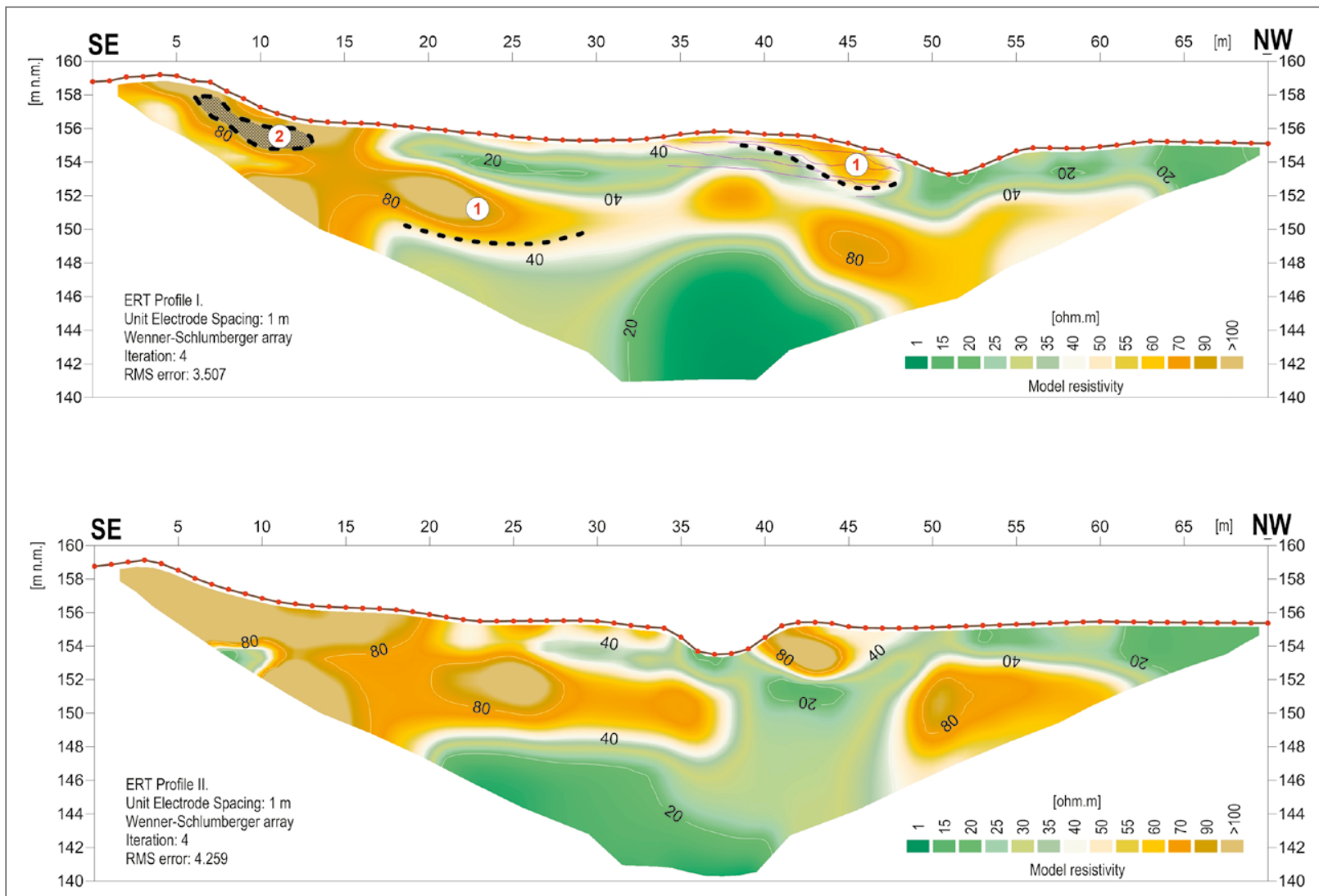

Obr. 3: ERT profily na zájmové lokalitě (1 - výplň ř́ínního koryta, 2 - hradební destrukce).

Fig. 3: ERT profiles on the locality (1 - deposits of fluvial channel, 2 - destruction of rampart). 


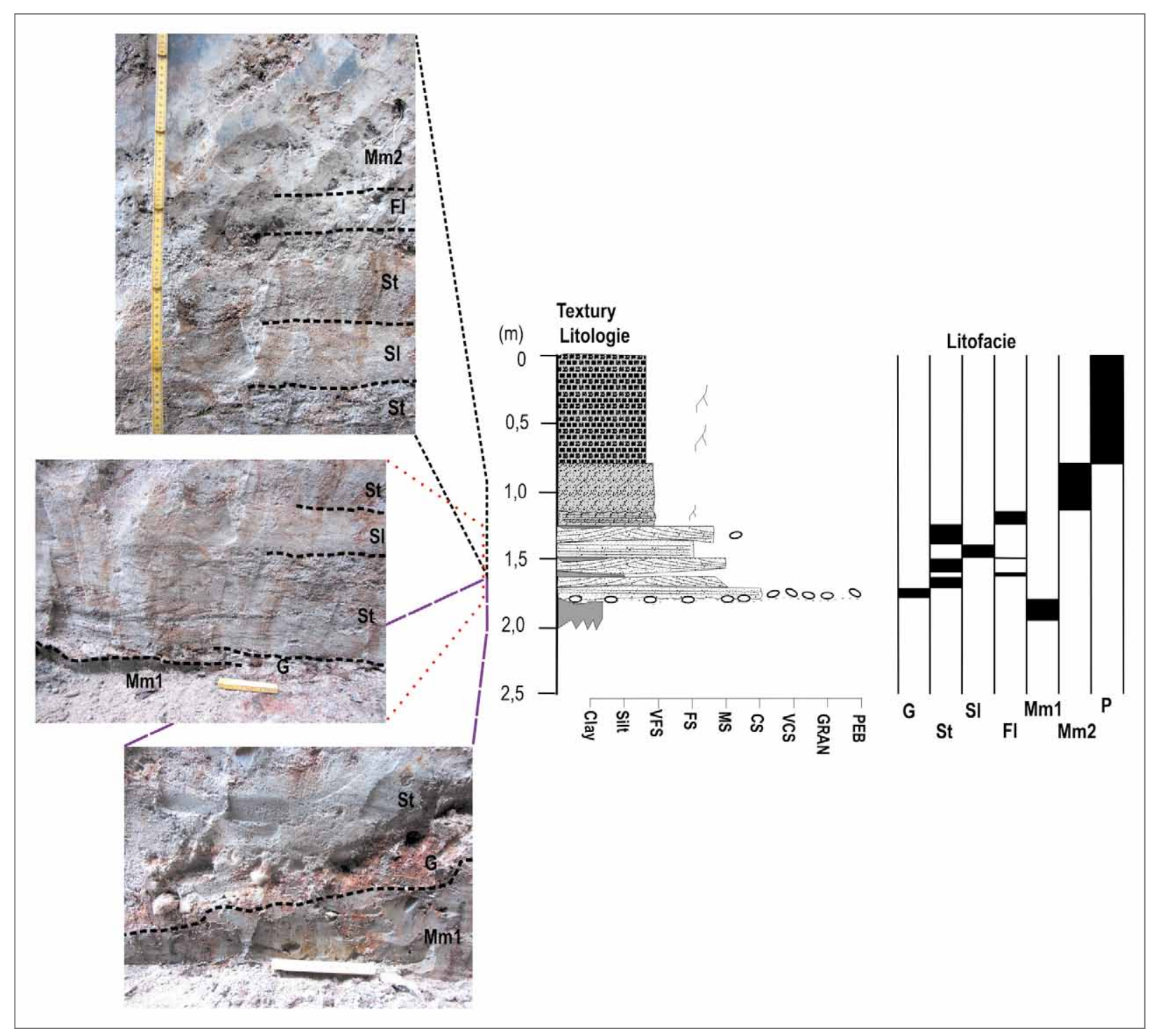

Obr. 4: Vybraný litologický profil (profil II dle obrázku 5) provedený v rámci stěny umělé rýhy s př́klady hodnocených litofacií. Fig. 4: Sedimentological log (log. No. II according to Fig. 5) of the artificial outcrop with figures of the studied lithofacies.

na obrázku 4. Prostorové rozšíření jednotlivých litofacií, pozice profilů a geologická situace $\mathrm{v}$ rámci výkopu je znázorněna na obrázku 5.

Prostorové rozšíření litofacií a především procesy jejich geneze vedly $\mathrm{k}$ vyčlenění dvou faciálních asociací, které mimo jiné odráží odlišná depoziční prostředí. Nejvyšší půdní horizont nebyl hodnocen, podobně jako navážky a výplň moderních zavodňovacích kanálů. Ve dně výkopu byla zjištěna zaražená dubová fošna. Za účelem jejího vyjmutí byla vyhloubena cca 1,5 m hluboká jáma. Její pozice je znázorněna v obrázku 5. Sedimenty odkryté v rámci této jámy také nejsou dále diskutovány vzhledem $\mathrm{k}$ nejasnostem $\mathrm{v}$ jejich prostorové distribuci.

Faciální asociace 1 (FA 1) je tvořena třemi litofaciemi tj. Mm1, Mm2 a Mm3. Jedná se o proměnlivě zbarvené (sytě šedé, zelenavě šedé, žlutavé, olivově zelené) rezavě hnědě smouhované jílovito-prachovité hlíny s velmi proměnlivou přítomností světle slídnatého jemnozrnného písku („hnízdovitá struktura“). Hlíny mají masivní vzhled a směrem $\mathrm{k}$ povrchu roste množství stop po kořenech. Bazální hlíny (Mm1) vykazují lokálně ostře omezené ukloněné laminy středozrnného rezavě hnědého špatně vytříděného písku a až $5 \mathrm{~cm}$ mocné neprůběžné polohy nevytř́íděného štěrku (až $3 \mathrm{~cm}$ velké valouny křemene) s podpůrnou strukturou hlinité matrix. Bazální hlíny tvoří ve výkopu nepravidelně deskovité těleso mírně ukloněné generelně $\mathrm{k} Z$. Tyto hlíny jsou bud' ostře erozně seř́iznuty sedimenty faciální asociace 2 , nebo gradačně přecházejí do nadložních hlín facie Mm2. Hlíny facie Mm2 jsou charakteristické nepravidelnou a místy výraznou prrítomností zuhelnatělé rostlinné hmoty. Mají gradační ploše ukloněnou bázi a konvexně vyklenutou svrchní plochu, díky korytovitému eroznímu seříznutí sedimenty faciální asociace 2 . Hlíny facie $\mathrm{Mm} 3$ deskovitě překrývají sedimenty facie Mm2 i sedimenty FA 2 . Tyto hlíny mají nepravidelnou bázi i svrchní plochu.

Faciální asociace 2 (FA 2) je tvořena čtyřmi litofaciemi tj. G, St, Sl a Fl. Charakteristická je ostrá erozní korytovitá báze FA 2 a celkově nahoru zjemňující trend její sedimentární sukcese. Bazální facie $G$ je tvořena špatně vytř́iděnými písky s valouny (křemen, ruly) až písčitým štěrkem. Valouny jsou zaoblené i polozaoblené. Mocnost 


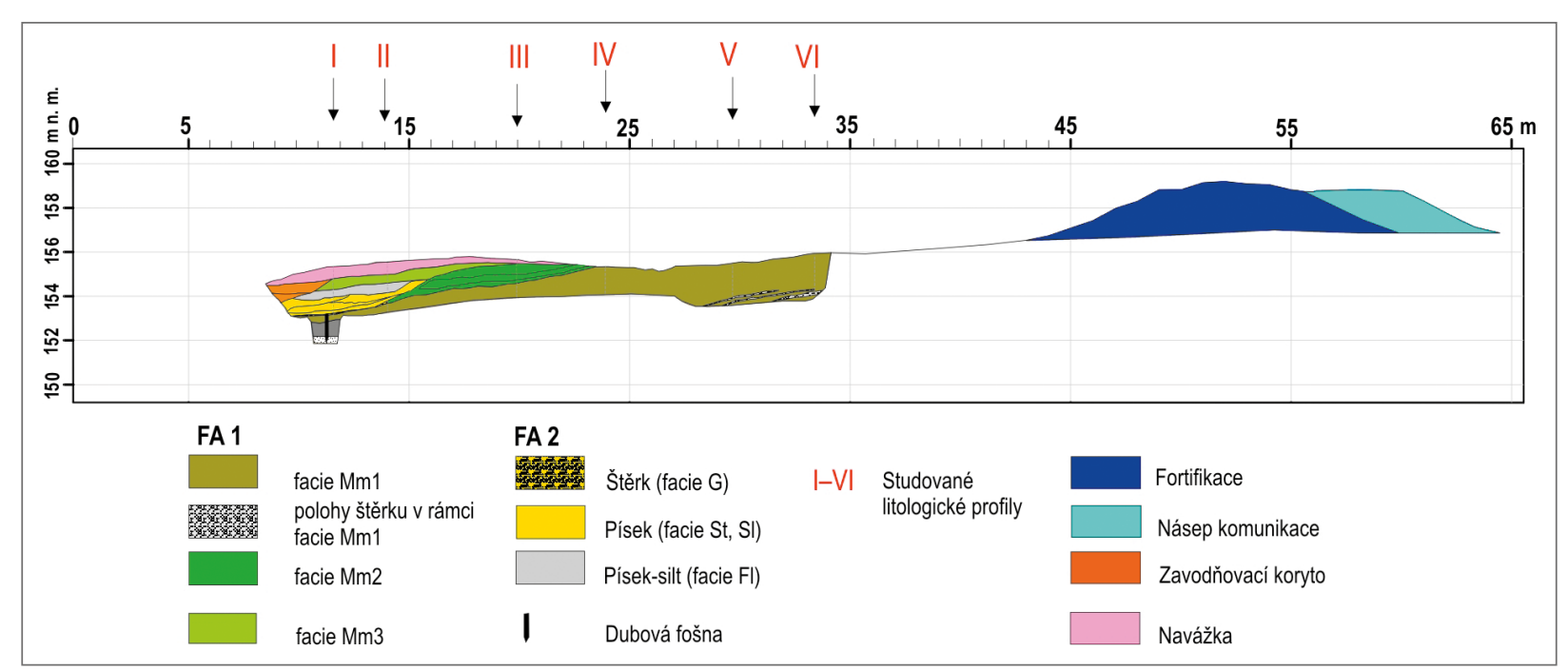

Obr. 5: Prostorové rozšíření jednotlivých litofacií, pozice profilů a geologická situace v rámci rýhy.

Fig. 5: Lateral distribution of the lithofacies within the studied wall of the artificial outcrop with position of the lithological logs.

polohy facie G je velmi nepravidelná (max. $6 \mathrm{~cm})$, zřetelná je ostrá erozní korytovitá báze a konkávní nepravidelný průběh. Laterálně přechází do neprůběžné polohy izolovaných valounů. Litofacie $G$ erozně seřezává sedimenty Mm1 (FA 1). V nadloží facie G je vyvinuto ploše korytovité písčité těleso představující hlavní část výplně koryta. V rámci tohoto tělesa je zřetelný nahoru zjemňující trend a opakovaná amalgamace výplně tělesa (cosety korytovitě šikmo zvrstvených písků litofacie St oddělené sety facie Fl př́padně Sl). Sedimenty litofacie St tvoří dominantní část FA 2. Sedimenty litofacie St jsou relativně dobře vytříděny $(\sigma \mathrm{I}=1,4)$. Střední velikost zrna Mz byla $1,9 \Phi$. Písek lze zrnitostně klasifikovat především jako středozrnný, zastoupení štěrkové frakce dosahuje max $1 \%$ (klasty do $1 \mathrm{~cm})$. Prachovitá frakce tvoří cca 5,2\% a jílovitá frakce pak $1,2 \%$ sedimentu. Světle šedé velmi jemnozrnné až jemnozrnné planárně laminované písky litofacie Sl tvoří deskovité těleso v rámci sedimentů litofacie St. Facie Sl je

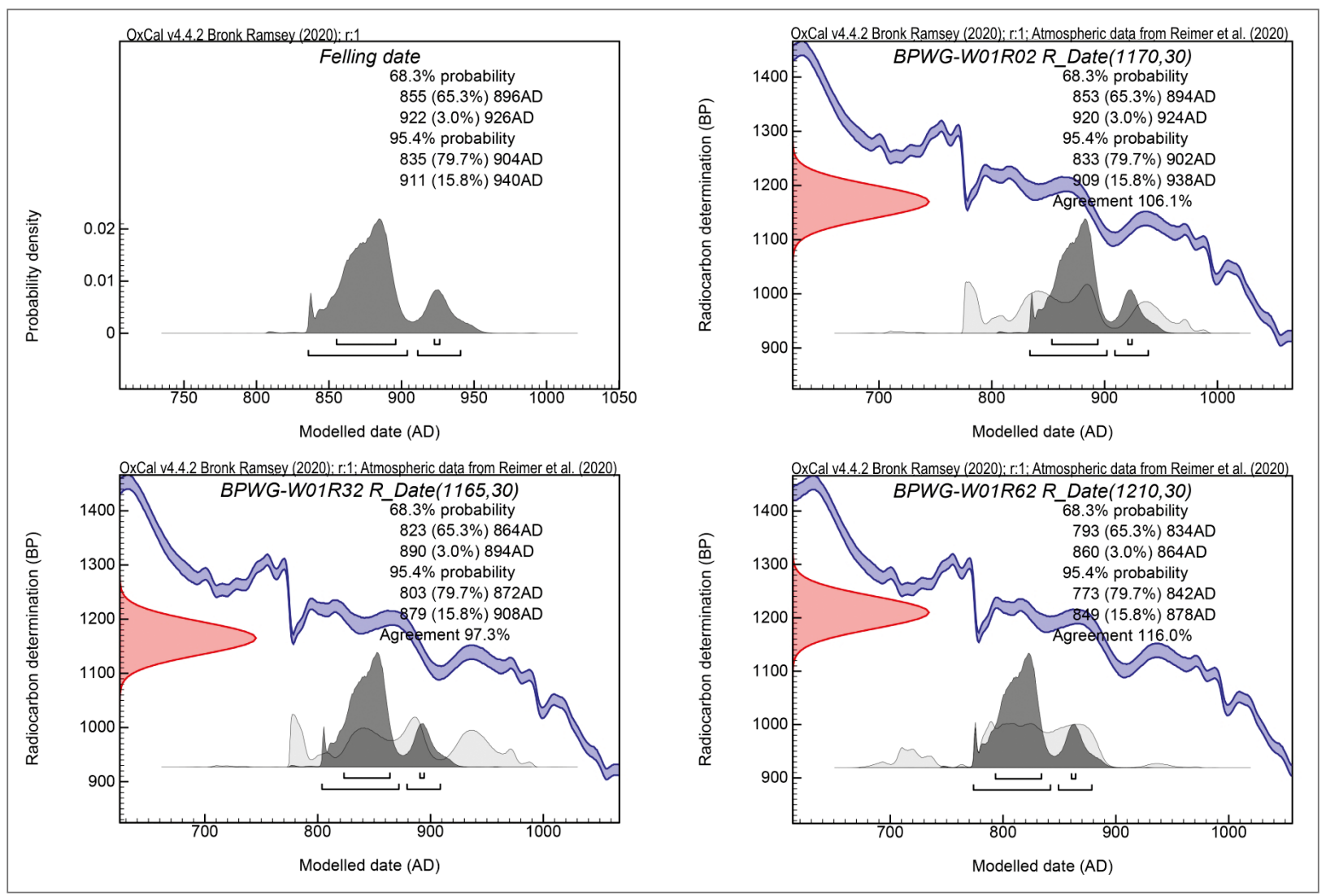

Obr 6: Výstupy radiokarbonové analýzy letokruhů kůlu konstrukce. Vlevo nahoře: interval data pokácení stromu. Ostatní: výsledky kalibrace pro vybrané letokruhy.

Fig. 6: Outputs radiocarbon analysis stake annual ring structure. Top left: tree felling interval datum. Others: calibration results for selected tree rings. 
Tab. 1: Stručný popis vyčleněných facií a jejich interpretace.

Tab. 1: Descriptive summary list of lithofacies of the studied deposits.

\begin{tabular}{|c|c|c|}
\hline Značka & Popis & Interpretace \\
\hline G & $\begin{array}{l}\text { Světle rezavě hnědý až žlutohnědý rezavě smouhovaný hrubozrnný písek s valouny (kře- } \\
\text { men, ruly) až písčitý štěrk. Valouny jsou zaoblené i polozaoblené, písek je špatně vytř́děný. } \\
\text { Mocnost polohy do } 6 \mathrm{~cm} \text {, místy mocnost „jednoho valounu“. Ostrá erozní korytovitá báze, } \\
\text { konkávní nepravidelný top. Laterálně přechází do neprůběžné polohy izolovaných valounů. }\end{array}$ & $\begin{array}{l}\text { Báze koryta, erozní „lag“. Inundite } \\
\text { sensu Durand et al. (1989). }\end{array}$ \\
\hline St & $\begin{array}{l}\text { Světle žlutošedý až bělavě žlutý místy rezavě smouhovaný jemnozrnný, jemnozrnný až } \\
\text { středozrnný, středožnný až hrubozrnný písek, světle jemně slídnatý. Korytovité šikmé } \\
\text { zvrstvení. Relativně dobř̌ vytř́íděný, velmi ojedinělý výskyt valounkủ do } 1 \mathrm{~cm} \text {. Mocnost } \\
\text { setů kolem } 10 \mathrm{~cm} \text {, rozdíly v zrnitosti jednotlivých setů v rámci cosetu. Nerovná konkávní } \\
\text { báze, nerovný konvexní top. Nepravidelně korytovitý tvar tělesa, vykliňující generelně k V. } \\
\text { Opakovaně amalgamované těleso (neprůběžné laminy facie } \mathrm{Fl} \text { ). Nahoru zjemňující trend. }\end{array}$ & $\begin{array}{l}\text { Spodní proudový režim, trakční depozi- } \\
\text { ce, migrace } 3 \mathrm{D} \text { valù/čeřin, relativně plo- } \\
\text { ché vnitrokorytové valy, sedimentace } \\
\text { za zvýšneného průtoku. Stř́ídání vyššího } \\
\text { a nižšího vodního stavu v korytě. }\end{array}$ \\
\hline $\mathrm{Sl}$ & $\begin{array}{l}\text { Světle šedý velmi jemnozrnný až jemnozrnný písek. Planární mírně ukloněná laminace. } \\
\text { Dobře vytř́iděný. Ostrá konvexní báze i top. Top často erozní. Max. mocnost do } 10 \mathrm{~cm} \text {. }\end{array}$ & $\begin{array}{l}\text { Vyšší rychlost proudění, trakční sedi- } \\
\text { mentace za zvýšeného průtoku, „přeliti“ } \\
\text { vnitrokorytových valü. }\end{array}$ \\
\hline $\mathrm{Fl}$ & $\begin{array}{l}\text { Světle šedý prachovitý velmi jemnozrnný písek až písčitý silt. Planární laminace lokálně } \\
\text { postižená pedogenezí a pronikáním kořenù. Relativně dobře vytříděný. Ostrá báze, max. } \\
\text { mocnost do } 15 \mathrm{~cm} \text {, často zachováno jako erozní relikt (čočka) v rámci facie St prrípadně } \\
\text { Sl. Gradační top (přechod do } \mathrm{Mm} 2 \text { ). }\end{array}$ & $\begin{array}{l}\text { Trakční sedimentace ze slábnoucího } \\
\text { proudu. Sedimentace za sníženého } \\
\text { průtoku. V nejvyšš́ch partiích postižení } \\
\text { pedogenní činností. }\end{array}$ \\
\hline $\mathrm{Mm} 1$ & $\begin{array}{l}\text { Sytě šedá, zelenavě šedá, žlutavá rezavě hnědě smouhovaná písčitá hlína. Masivní. Velmi } \\
\text { proměnlivá prrítomnost světle slídnatého jemnozrnného písku („hnízdovitá). Báze nezná- } \\
\text { má, svrchní hranice ostrá erozní konkávní (v nadloží facie St či G) př́ípadně nepravidelná } \\
\text { gradační (v nadloží facie Mm2). Lokálně zjištěny ukloněné laminy středozrnného rezavě } \\
\text { hnědého špatně vytř́děného písku a až } 5 \mathrm{~cm} \text { mocná neprůběžná vrstva štěrku s podpưrnou } \\
\text { strukturou hlinité matrix. Štěrk je tvořen až } 3 \mathrm{~cm} \text { velkými (osa A) polozaoblenými valouny } \\
\text { křemene. Ostrá báze i top těchto vložek. }\end{array}$ & $\begin{array}{l}\text { Dominuje sedimentace ze suspenze, } \\
\text { občanýy př́nos materiálu prouděním - } \\
\text { trakční sedimentace (přelití koryta?). } \\
\text { Mimobřežní a břežní sedimenty. Starší } \\
\text { „povodňové hlíny“. }\end{array}$ \\
\hline $\mathrm{Mm} 2$ & $\begin{array}{l}\text { Olivově zelenošedá, rezavě smouhovaná jílovito-prachovitá hlína. Proměnlivá přítomnost } \\
\text { písčité frakce a zuhelnatělých zbytků rostlin. Místy stopy po kořenech. Neostrá gradační } \\
\text { báze. }\end{array}$ & $\begin{array}{l}\text { Dominuje sedimentace ze suspenze, } \\
\text { občasný př́nos materiálu prouděním - } \\
\text { trakční sedimentace (přelití koryta?). } \\
\text { Mimobřežní a břežní sedimenty. Starší } \\
\text { „povodňové hlíny“. }\end{array}$ \\
\hline $\mathrm{Mm} 3$ & $\begin{array}{l}\text { Světle šedozelená či zelenošedá, rezavě smouhovaná jemně písčitá hlína. Hojné stopy po ko- } \\
\text { řenech. Masivní. Nepravidelný průběh báze i top. }\end{array}$ & $\begin{array}{l}\text { Suspenzní i trakční depozice. Mimo- } \\
\text { korytovité sedimenty - přeliv z koryta. } \\
\text { Mladší „povodňové hlíny“. }\end{array}$ \\
\hline
\end{tabular}

tvořena jemnozrnnými až velmi jemnozrnnými prachovitými písky. Sedimenty této litofacie jsou relativně hůř̀e vytrríděny $(\sigma \mathrm{I}=1,7)$. Střední velikost zrna $\mathrm{Mz}$ byla $4,6 \Phi$. Zastoupení prachovité frakce dosahuje $36 \%$ a frakce jílovitá tvoří 6,8 \%. Nejvyšší partie FA 2 jsou pak tvořeny prachovitým velmi jemnozrnným pískem až písčitým siltem facie Fl. Tyto planárně laminované dobře vytříděné sedimenty jsou lokálně postiženy pedogenezí a pronikáním kořenů, a tak gradačně přecházejí do litofacie $\mathrm{Mm} 2$. Datování metodou OSL odebraného vzorku fluviálních písků (facie St) přineslo stáří $1,183(72) \mathrm{ka}$, po přepočtu datum $767 \pm 72$ AD.

Dřevěný opracovaný prvek vytažený z koryta, štípa - štípáním opracovaný dub lichoběžníkovitého průřezu o rozměrech $11 \times 16 \mathrm{~cm}$ a délce $130 \mathrm{~cm}$, měl sice dostatečný počet letokruhů k provedení dendrochronologické analýzy, ale naměřené kř̌ivky nebylo možné jistě přiřadit $\mathrm{k}$ žádnému období. Proto byly odebrány tři vzorky z druhého, třicátého druhého a šedesátého druhého letokruhu. Ty byly radiokarbonovou analýzou datovány do 9. století (obr. 6 A-D). Rámcově zařazené dřevo se pak Jaroslav Škojec pokusil přesněji datovat. Bohužel ani jedno měření, včetně střední křivky vytvořené z obou měření (j. 365-366 a BrPol), při datování standardy (czgestom2001, jihomor-m, mikst4-M, prages-m) nevykazovalo hodnoty umožňující vzorek spolehlivě datovat. Pro měření j. 365 vychází nejvýraznější datum 842 AD (datum $836+6$ neměřitelných letokruhů), pro měření j. 366 je to datum $841 \mathrm{AD}$ (datum $825+16$ neměřitelných letokruhů) nebo datum $860 \mathrm{AD}$ (datum 844 + 16 neměřitelných letokruhů). Pro střední křivku BrPol je to datum $842 \mathrm{AD}$ (datum $836+6$ neměřitelných letokruhů). Nejčastější výsledek kombinací měření a dostupných standardů se pohybuje mezi roky 841 a $842 \mathrm{AD}$.

Odebrané palynologické vzorky byly prozatím zpracovány ze tří poloh - ze sedimentu v okolí zaraženého kůlu (před obdobím velkomoravského osídlení (VM), vz. č. 3 - litofacie F), u jeho vrcholu (předpokládané VM, vz. č. 2 - lifacie Mm1) a nad ním (mladší období, vz. č. 1 - laminy facie Fl uvnitř litofacie St) - viz tab. 1. V sedimentech koryta tvořených písčitou frakcí bez jílovité příměsi nebyla pylová zrna zjištěna (tafonomie). Pouze 3 z 8 vzorků obsahovaly dostatečné množství palynomorf (více než 100) pro sestavení pylového diagramu (obr. 7). V ostatních vzorcích bylo nalezeno max. do 20 palynomorf, které se nevymykaly celkovému charakteru bohatších spekter. Ve všech vzorcích převládalo zastoupení bylin (56-75 \%), dřeviny tvořily $25-44 \%$ společenstva. Nejvyšší podíl dřevin byl neočekávaně zaznamenán ve vrstvě předpokládaného slovanského osídlení. Dřeviny obsahovaly prvky mezofilních habrových doubrav (Quercus - dub, Tilia - lípa, Carpinus - habr) i měkkého (Salix - vrba, Fraxinus - jasan) a tvrdého luhu (Alnus - olše, Ulmus - jilm). Ojediněle byla v této vrstvě nalezena i zrna buku (Fagus) a smrku (Picea). Ve všech vrstvách byla běžně nalézána zrna borovic (Pinus), které se zde vyskytují převážně jako vegetace písčitých hrúdů. 


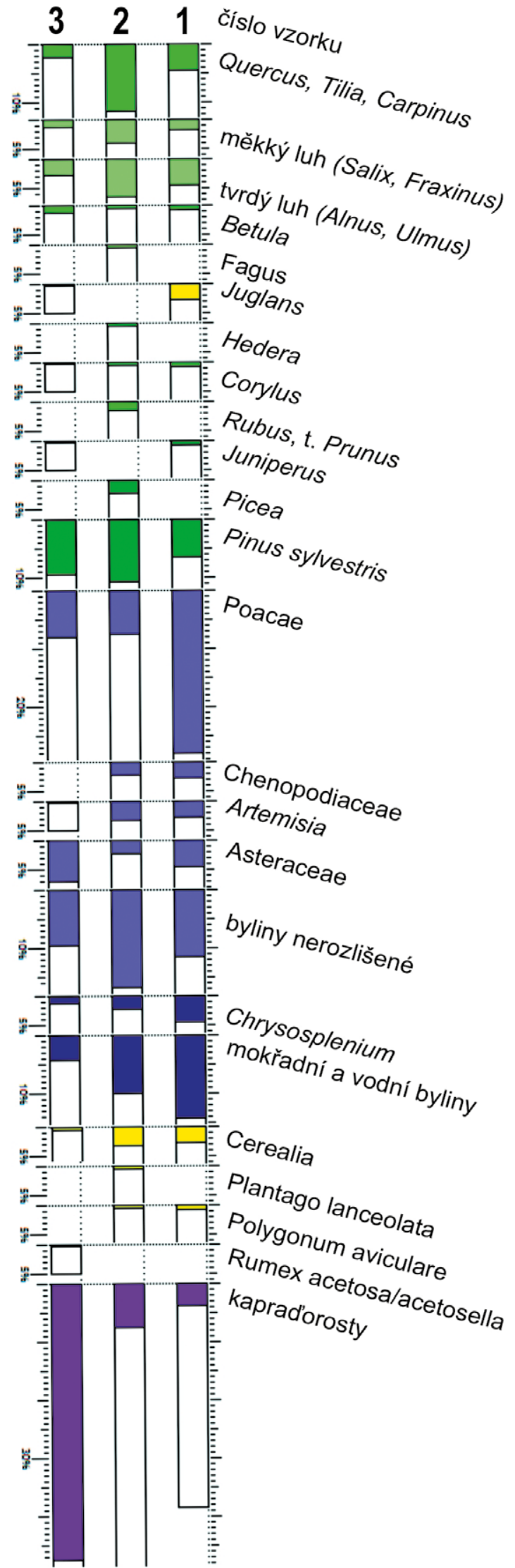

Obr. 7: Pylový diagram.

Fig. 7: Pollen diagram.
Kulturní rostliny byly zastoupené obilovinami (Cerealia) a druhotnými ukazateli, zejména plevely (Plantago lanceolata, Polygonum aviculare) a byly detekovány ve svrchních 2 vrstvách. V sedimentu ze spodní části kolem nalezeného dřeva tyto prvky byly zjištěny pouze ojediněle. Stejný trend lze pozorovat i u rostlin z dusíkem nabohacených stanovišt' - Chenopodiaceae a Artemisia.

Z pylového diagramu je patrný postupný nárůst podílu vlhkomilných a pobřežních rostlin. V nejspodnějším vzorku jsou velmi výrazně zastoupené spory kapradin. Směrem do nadloží přibývá rostlin vlhkých okrajů vod - Cyperaceae, Caltha, Lythraceae. V nejvyšším vzorku i Typha/Sparganium, Valeriana, Alisma.

\section{Interpretace a závěry}

Vizuální podobnost geoelektrických profilů byla dobrým předpokladem pro jejich interpretaci. Určité posuny v konkrétní distribuci jednotlivých polí jsou nejspíše odrazem průběhu sedimentárních těles generelně $\mathrm{k}$ měřeným profilům. $\mathrm{V}$ terminálních levých tj. východních částech profilů lze jednoznačně identifikovat zbytky fortifikace hradiště (tj. čelní na sucho stavěná kamenná zed’ s hlinitou výplní jádra, v jejím předpolí nejspíše destruovaná čelní zed'). Dále provedené geoelektrické měření (ERT) indikovalo přítomnost dvou fluviálních koryt, z nichž jedno (blíže hradišti i blíže povrchu) bylo výkopem bezpečně identifikováno.

Výplň fluviálního koryta je tvořena sedimenty FA 2. Litofaciální a architekturní analýza výplně koryta vedla k vyčlenění několika fází jeho vývoje. Erozní fáze je doložena bazální konkávní plochou a přítomností štěrkového rezidua. Samotná výplň koryta je tvořena převážně středozrnnými a jemnozrnnými korytovitě zvrstvenými písky, př́ípadně jemnozrnnými písky planárně laminovanými. Mocnost jednotlivých setů, evidence neprůběžných prachovito-jílovitých lamin, tvar těles cosetů a povrchů sedimentárních těles ukazuje na dominující sedimentaci $\mathrm{v}$ rámci vnitrokorytových valů a značné rozdíly v energii vodního proudu i průtoku. Lze doložit akreci fluviálních valů především ve směru po proudu ale i laterálně. Sedimenty nejvyšší partie výplně koryta odrážejí fázi jeho opuštění (avulzi). Šírka koryta rozhodně přesahovala $6 \mathrm{~m}$ a jeho hloubku lze odhadnout mezi 0,5-1,0 m. Výsledky datování výplně fluviálního koryta odpovídají 8. až 9. století, což se věkově přibližně shoduje s velkomoravským osídlením hradiště. Podobně doba pokácení stromu, ze kterého pochází zahrocená štípa dubového kmene, vyzvednutá ze dna zachyceného koryta, byla dendrochronologicky odhadnuta do první poloviny 9. století. Nejedná se v žádném př́ípadě o finální datum, protože naměřené křivky nevykazovaly hodnoty, které by umožnily spolehlivou dataci. Výsledné datum bude muset být potvrzeno dalšími vzorky z jiných dřev, které předpokládáme v nejbližším okolí. Dubová štípa vzhledem ke své poloze ve dně koryta $\mathrm{v}$ prostoru před očekávanou západní bránou a orientaci $\mathrm{k}$ převládajícímu směru destrukce opevnění nevylučuje možnost, že se jedná o část konstrukce mostu nebo mostní lávky překonávají koryto řeky. Ta s největší pravděpodobností byla jednou $\mathrm{z}$ hlavních fortifikačních 
linií velkomoravského Pohanska. Předběžné datum stětí stromu někdy v letech 841 nebo 842 , pokud se ukáže být platné, bude první absolutní dendrochronologické datum z první poloviny 9. století, které známe z prostoru jádra velkomoravského útvaru. Není vyloučeno, že strom sice byl st’at v těchto letech, ale jeho skutečné využití bylo pozdější. Také fluviální val mohl alespoň částečně vznikat současně s existencí fortifikace a říční koryto mohlo představovat součást obranného systému hradiště, když bylo využito v jeho předpolí.

Sedimenty FA 1 jsou interpretovány jako sedimenty mimokorytovité odrážející převážně sedimentaci za zvýšeného vodního stavu (přelití koryta) a pedogenní procesy. Tyto sedimenty představují geometricky i stratigraficky nadloží, laterální ekvivalent i podloží výplně hodnoceného říčního koryta. Tato situace ukazuje na generování sedimentu FA 1 během různých časových etap vývoje nivy řeky Dyje i na složité prostorové vztahy jednotlivých etap vývoje zdejších korytovitých a mimokorytovitých sedimentů. Také konkrétní podmínky formování jednotlivých dílčích facií FA 1 nebyly identické, což je zřejmé z částečně odlišných strukturních a texturních znaků. Sedimenty FA 1 však nebyly cílem studia.

Z pylových spekter všech studovaných pozitivních vzorků lze interpretovat mozaikovitý charakter krajiny. Vegetace byla tvořená mezofilními doubravami a lužními porosty s volnými bezlesými polohami. V nejspodnějším vzorku (vz. č. 3) bylo zastiženo vysoké procento kapradin. Tento fakt spolu s výrazným nedostatkem dřevin by mohl být interpretován jako výrazné odlesnění, kde kapradiny porůstaly člověkem narušené, ale zemědělsky málo využívané (nalezeno 1 zrno Cerealia) zamokřené plochy. Stáří sedimentu nebylo stanoveno, ale podle palynologického obsahu patrně šlo o doklady staršího, předslovanského osídlení. Ve svrchních vzorcích (vz. č. 2 - VM, vz. č. 1 nad VM) jsou více patrné doklady pěstovaných rostlin (obilí, ořešák Juglans, př́ípadně chmel/konopí Humulus/ Cannabis). Zároveň zde vzrůstá poměr indikátorů vzrůstu obsahu dusíku (merlíkovité - Chenopodiaceae, pelyněk Artemisia, rdesno ptačí - Polygonum aviculare). Zvyšuje se rovněž zastoupení a pestrost bylin rostoucích na zamokřených substrátech a okrajích vody. Tyto dosahují maxima v nejsvrchnější poloze. Zde současně nabývá maximum zastoupení trav (28\%). Z charakteru vegetace lze interpretovat přibývání mokřadní vegetace do mladších fází a zvyšující se zemědělské aktivity.

\section{Poděkování}

Výzkum je podporován projektem GAČR GA20-18929S. Za pečlivé provedení recenze a cenné pripomínky jsme vděčni Danielu Šimíčkovi a Jaroslavu Kadlecovi. 


\section{Literatura}

Beug, H. J. (2004). Leitfaden der Pollenbestimmung für Mitteleuropa und angrenzende Gebiete. - Verlag Dr. Friedrich Pfeil, München.

Bronk Ramsey, C., Lee, S. (2013). Recent and Planned Developments of the Program OxCal. - Radiocarbon, 55, 2, 720-730. https:// doi.org/10.1017/S0033822200057878

Císlerová, M., Šanda, M., Zumr, D., Jelínková, V., Hlavice, M., Vacek, J. (2006). Terénní průzkum v Karlíně. - In: Udržitelná výstavba 2, 177-186. ČVUT v Praze, Fakulta stavební, Praha.

Dostál, B., Štelcl, J. (1985). O rezultatach vtorogo etapa archeologičeskogo i petroarcheologičeskogo issledovanija vostočnych vorot na velikomoravskom gorodišče Pogansko pod g. Břeclav. - Scripta Facultatis Naturalium Universitatis Purkynianae Brunensis, 15, 1, 3-26.

Doláková, N., Roszková, A. Přichystal, A. (2010). Palynology and Natural Environment in the Pannonian to Holocene Sediments of the Early Medieval Centre Pohansko near Breclav (Czech Republic). - Journal of Archaeological Science, 37, 10, 2538-2550. https://doi.org/10.1016/j.jas.2010.05.014

Dresler, P. (2011). Opevnění Pohanska u Břeclavi. Brno. - In: Měřínský Z., Klápště J. (eds): Dissertationes Archeologicae Brunenses/Pragensesque. Masarykova Univerzita, Brno.

Dresler, P. (2016). Břeclav-Pohansko VIII. Hospodářské zázemí centra nebo jen osady v blízkosti centra? - University press, Masarykova univerzita, Brno.

Dresler, P., Přichystalová, R., Macháček, J. (2014). Archeologický výzkum severovýchodního předhradí Pohanska u Břeclavi 2012-2013. - Jižní Morava, 50, 45-57.

Durand, M., Meyer, R., Avril, G. (1989). Le Trias détritique de Provence, du Dome de Barrot et du Mercantour. Publication de lÁssociation des Sédimentologistes Francais, 6, 1-135.

Folk, R. L., Ward, W. (1957). Brazos River bar: a study in the significance of grain-size parameters. - Journal of Sedimentary Petrology, 27, 3-26. https://doi.org/10.1306/74D70646-2B21-11D7-8648000102C1865D

Havlíček, P. (1999). Die geologische Verhältnisse in der Umgebung der Siedlungsagglomerationen der groß-mährischen Machtzentren Mikulčice und Staré Město - Uherské Hradiště. - In: Poláček, L., Dvorská, J. (eds): Probleme der mitteleuropäischen Dendrochronologie und naturwissenschaftliche Beiträge zur Talaue der March, Internationale Tagungnen in Mikulčice V, 181-198. Archeologický ústav AV ČR, Brno.

Havlíček, P. (2001). Geologická stavba velkomoravského mocenského centra Břeclav Pohansko a jeho okolí. - Zprávy o geologických výzkumech v roce 2000, 71-73.

Havlíček, P. (2004). Geologie soutokové oblasti Dyje s Moravou. - In: Hrib, M., Kordiovský, E. (eds): Lužní les v Dyjsko-moravské nivě, 11-19. Břeclav.

Havlíček, P, Smolíková, L. (2002). Subfosilní polygenetická pseudočernozem v navátých píscích při soutoku Dyje s Moravou („Barvínkův hrúd“), Jižní Morava. - Geologické výzkumy na Moravě a ve Slezsku v roce 2001 9, 2-3.

Havlíček, P., Břízová, E., Hošek, J., Sidorinová, T. (2016). Geologický výzkum na soutoku Dyje, Kyjovky a Moravy. - Zprávy o geologických výzkumech, 49, 195-202.

Macháček J., Doláková N., Dresler P., Havlíček P., Hladilová Š., Přichystal A., Roszková A., Smolíková L. (2007). Raně středověké centrum Na Pohansku u Břeclavi a jeho prŕrodní prostředí. - Archeologické rozhledy LIX, 2, 278-314.

Nehyba, S., Dvořáková, M., Doláková, N., Dresler, P. (2018). Kvartérní sedimenty na Severním předhradí lokality Pohansko u Břeclavi. - Geologické výzkumy na Moravě a ve Slezsku, 25, 34-40. https://doi.org/10.5817/GVMS2018-1-2-34

Nemec, W. (2005): Principles of lithostratigraphic logging and facies analyses. - 28s. Institutt for geovitenskap, University of Bergen, Bergen.

Petr, L., Petřík, J., Macháček, J., Dresler, P., Prištáková, M., Lendáková, Z. (2015). Vztah aluvia Dyje a ranně stř̌edověkého osídlení na Pohansku u Břeclavi: paleoekologie a geoarcheologie. - In: Nohálová, H., Káňa, V., Březina, J. (eds): 21. Kvartér. 21st Quaternary Conference, 39. Masarykova univerzita, Brno.

Petř́ík J., Doláková N., Nehyba S., Lendáková Z., Prištáková M., Adameková K., Petr L., Dresler P., Macháček J. (2018). Zaniklý meandr u severního předhradí archeologické lokality Pohansko u Břeclavi. - Geologické výzkumy na Moravě a ve Slezsku, 25, 1-2, 41-48. https://doi.org/10.5817/GVMS2018-1-2-41

Reille, M. (1995). Pollen et Spores d'Europe et d'Afrique du nord. - Laboratoire de Botanique Historique et Palynologie, Marseille. Reimer, P. J., Bard, E., Bayliss, A., Beck, J. W., Blackwell, P. G., Bronk Ramsey, C., Buck, C. E., Cheng, H., Edwards, R. L., Friedrich, M., Grootes, P. M., Guilderson, T. P., Haflidason, H., Hajdas, I., Hatté, C., Heaton, T. J., Hoffmann, D. L., Hogg, A. G., Hughen, K. A., Kaiser, K. F., Kromer, B., Manning, S. W., Niu, M., Reimer, R. W., Richards, D. A., Scott, E. M., Southon, J. R., Staff, R. A., Turney, C. S. M., van der Plicht, J. (2013). IntCal13 and Marine13 Radiocarbon Age Calibration Curves $0-50,000$ Years cal BP.

Tucker, M. ed. (1988). Techniques in Sedimentology. - 394s. Blackwell Science.

Voňka, D. (1985). Geofyzikální průzkum na archeologické lokalitě Pohansko - MS, magisterská diplomová práce, Univerzita Karlova.

Walanus, A., Nalepka, D. (1999). POLPAL. Program for counting pollen grains, diagrams plotting and numerical analysis. - Acta Paleobotanica, 2, 659-661.

Walker, R. G., James, N. P. (1992). Facies Models. Response to sea level changes. - 380s. Geological Association of Canada, Toronto.

Zumr, D., Levorová, M., Císlerová, M. (2009). Využití ERT pro kvantitativní vyhodnocení infiltračních experimentů. - In: Udržitelná výstavba 5, 218-222. ČVUT, Fakulta stavební, Praha. 